\title{
Effect of Adding Crude Glycerol Produced from Biodiesel Industry on Biogas Production from Anaerobic Digestion of Cattle Dung Zayed, M. F. Agricultural Engineering Research Institute
}

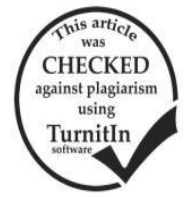

\section{ABSTRACT}

Effect of crude glycerol addition to cattle dung on biogas generation and methane percentage was studied. Five percentages of crude glycerol were added to cattle dung during the anaerobic digestion process. The crude percentages ranged from 1 to $5 \%$ based on total solids (from 4 to $20 \mathrm{~g}$ ). The experiments were conducted at mesophilic conditions of ambient temperature $\left(27 \pm 2{ }^{\circ} \mathrm{C}\right)$ and $40{ }^{\circ} \mathrm{C}$. Twelve batch-digested units were used for laboratory experiments procedure. The digested units were divided to two groups with six digested units for everyone. The first group was operated at ambient temperature $\left(27 \pm 2{ }^{\circ} \mathrm{C}\right)$. While, the second group was operated at Forty degree centigrade. The full capacity of each digested unit was 5 Liters while, the working capacity was 4 Liters. The digester feeding consists of $3.2 \mathrm{~L}$ of cattle dung and $0.8 \mathrm{~L}$ of inoculum. Five digesters of every groups were fed with different percentages of crude (from 1 to 5\%) namely G1, G2, G3, G4, and G5 in addition of G0 (control digester with 0 percentage of crude).The obtained results showed that the addition of crude glycerol to cattle dung during anaerobic digestion increased the biogas production rate and consequently the total biogas production at different temperature levels. Moreover, increasing the percentage of crude glycerol added increase the biogas production reached the maximum average biogas production rate of 0.212 and $0.296 \mathrm{~L} / \mathrm{L} / \mathrm{day}$ at G5 (5\% crude glycerol added about $20 \mathrm{~g}$ ) and different temperature levels of $27{ }^{\circ} \mathrm{C}$ and $40{ }^{\circ} \mathrm{C}$ respectively as compared with G0 $(0$ crude glycerol added). The increasing ratios were; 13.60 and $17.89 \%$ at the same temperatures respectively. Moreover, the total biogas production reached the maximum values of; 51.489 and $59.279 \mathrm{~L}$ at the treatment of G5 and the same temperatures respectively, with increasing ratios of 14.27 and $18.08 \%$ at the same temperatures as compared with G0. The maximum value of methane content was $66 \%$ with increasing ratio of $8.28 \%$ and it was occurred at $5 \%$ crude glycerol and temperature of $40{ }^{\circ} \mathrm{C}$.

Keywords: Anaerobic digestion, Biogas, Glycerol, Cattle manure, Methane.

\section{INTRODUCTION}

Expanding in energy production from natural sources is important to avoid greenhouse gas emissions, rationalize the fossil fuels uses and limits environmental pollution.

For securing energy resources, future strategies include technologies for producing bioethanol, biodiesel and biogas (Dharmadi et al., 2006 and Viana et al., 2012). Biogas is the most widely used types of renewable energy all over the world. However, its use in Egypt has not yet developed similarly. During the producing process of biodiesel by trans esterification reaction, about $10 \%$ wt of glycerol was produced as by-product (Chozhavendhan et al., 2016). The general characteristics of obtained crude glycerol from biodiesel or oleo chemical plant are; dark brown color liquid, bad smell and higher pH (Ayoub and Abdullah 2012).

Anaerobic digestion is the degradation process of organic matter by a mixed population of microorganisms in the absence of oxygen, to produce biogas which consists of a mixture of methane and carbon dioxide. only a few studies were be proceeded on biogas production from glycerol, and the majority of them was focused on the valorization of crude industrial glycerol. Meanwhile, Erin et al., (2016) stated that, the crude glycerol prices was around 200-220 US \$/ton. Moreover, Fountoulakis et al., (2010); and Robra et al., (2010) reported that the crude glycerol can be added in co-digestion with other wastes such as municipal solid wastes, agroindustrial by-products and cattle slurry to maximize the methane production using a continuous stirred tank reactor (CSTR). During this process, bacteria convert insoluble carbohydrates to soluble derivatives. Then the soluble sugars and amino acids are converted to carbon dioxide, hydrogen, ammonia and organic acids by acidogenic bacteria. Nextly, acetic acid, ammonia, carbon dioxide and hydrogen are produced from the fermentation products of the previous step using the acetogenic bacteria. Finally, the products of acidgenesis and acetogenesis are converted to methan and carbone dioxid by methanogens (Grady Jr et al., 2011). Another feature was, the solid remainder from anaerobic degradation can be used as an organic fertilizer for arable land
(Waala et al., 2016).This strategy is known to balance the nutrient content of the mixture and to reduce the effect of inhibitory compounds from substrates throughout the $\mathrm{AD}$ process (Holm-Nielsen et al., 2008; Mata-Alvarez et al., 2014).

Through the recent decade, a surplus production of the biodiesel industry resulted in increasing the glycerol production and a significant decrease in crude glycerol prices (Yazdani and Gonzalez, 2007). Glycerol is the carbon source for biological processes such as anaerobic digestion and fermentation. However, the glycerol produced from biodiesel industry is known as "crude glycerol" and it contains some impurities such as fatty acid methyl esters, salts and methanol (Leoneti et al., 2012 and Ayoub and Abdullah 2012). Anaerobic digestion of glycerol with biomass is used for generating biogas, which consists of methane and carbon dioxide. Siles Lopez et al., (2009) studied the anaerobic digestion of glycerol at mesophilic temperatures using granular and non-granular sludge in batch laboratory-scale reactors. A major challenge in the fermentation of low-grade crude glycerol, is to obtain microbial strains tolerant to under-able inhibitory components, such as salts and organic solvents which are presented in crude glycerol (Varrone et al., 2015).

Da Silva et al., (2009) found that glycerol is an attractive alternative for use through its co digestion with other wastethe resulted in increase biogas production with about $0.74 \mathrm{~L}$ per $\mathrm{mL}$ glycerol added. This is because the glycerol is readily biodegradable and has a suitable $\mathrm{pH}$ for anaerobic processes, and there are varieties of microorganisms that use glycerin as a carbon source in the anaerobic process. Houcinat et al., (2018) investigated the effect of temperature, retention time and glycerol concentration, on the efficiency of gasification, gas production and lower calorific value (LCV). The results showed that maximum gasification efficiency, $\mathrm{H} 2$ and $\mathrm{CO}$ production and LCV were obtained at a temperature of $809.36^{\circ} \mathrm{K}$, a retention time of $10 \mathrm{~s}$ and glycerol concentration of $5 \%$ by weight. Fierro et al., (2016) investigated the effects of glycerol concertation on inhibition of co-designation of swine manure and glycerol. They found 
that an addition of glycerol up to $8 \% \mathrm{~V} / \mathrm{V}$ caused a system failure due to high concentration of $\mathrm{H} 2 \mathrm{~S}$ and VFA, and thus to achieve a complete degradation of proteins and lipids, a post-stabilization stage was necessary. This co- digestion effect was highest with glycerol concentrations of $3 \%$ to $6 \%$ in hog manure with total solids content of about $4 \%$. Also, Amon et al., (2006) found that for co-digestion of manure with glycerol in semi-continuous lab digesters, the addition of glycerol should not exceed $6 \%$ by volume to ensure stable operation. Holm-Nielsen et al., (2008) showed that glycerol concentration of $3 \%$ (vol) was easy to manage and gave increasing biogas yields. While, when the glycerol concentration increased from 5 to $7 \mathrm{~g} / \mathrm{L}$ in the digester, methane was significantly reduced because of organic overloading.

As bio-diesel production is rapidly growing all over the world, a surplus of crude glycerol in global scale is to be expected (Demirbas, 2007), and also a proportional increase of crude glycerol (CG) as waste by-product. For efficient utilization of $\mathrm{CG}$, bioconversion process to hydrogen production by dark fermentation can be considered as an energy efficient and sustainable fuel generation option. Consequently, utilization of electricity generated from biogas will surely reduce the total energy input. Then the net energy for different feedstocks will have a positive value (Vinayak et al., 2016). Extensive researches were being conducted to address the environmental problems, which produced from the depletion of fossil fuels and the emission of greenhouse gases, which contribute to global climate change using the farm and industrial wastes. Many studies have reported that an integration of crude glycerol with other systems for energy

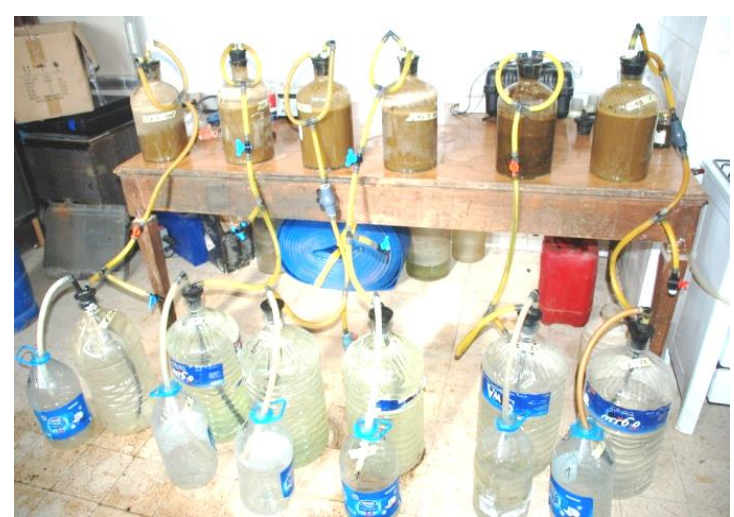

a: Experimental process at $27^{\circ} \mathrm{C}$

Fig. (1): Schematic of laboratory batch anaers at $40^{\circ} \mathrm{C}$

The raw cattle manure used in the experiments was obtained from animal farm, faculty of Agricultural, Alexandria University. The obtained cattle manure was chemically analyses to determine its characteristics Table (1).

Table 1.Chemical analysis of cattle manure.

\begin{tabular}{lc}
\hline Contents & Value (\%) \\
\hline Total Solids (T.S) & 22.86 \\
Volatile Solids (T.V.S) & 73.12 \\
Total Organic Carbon (T.O.C) & 42.41 \\
Total Nitrogen (T.N) & 1.64 \\
Carbon to Nitrogen ratio (C/N ratio) & $23.40: 1$ \\
pH & 7.86 \\
\hline
\end{tabular}

The cattle manure was diluted with water to achieve the desirable total solids of digestion materials production is a necessary option despite the impurities in crude glycerol, which benefit in some processes (Nartkeret al., 2014; Varrone et al., 2015; Fierro et al., 2016; Flach et al., 2017; Quan et al., 2017 and Chozhavendhan et al., 2018).

Crude glycerol, obtained from a biodiesel production process, was tested to assess the impact of impurities in the crude glycerol on digestion efficiency. Therefore, this research study focused on the addition of variable concentrations of glycerol to cattle manure in a batch-feed digester system in order to evaluate biogas production and its methane content. A variety feeding ratios of glycerol to manure were investigated to determine the suitable feeding regimes.

\section{MATERIALS AND METHODS}

The experiments working were conducted in the Biogas Laboratory of Tractors and Machinery Test and Research Station, Alexandria Governorate. Twelve batchdigested units were used to evaluate the effect of crude glycerol addition to cattle dung in anaerobic digestion process on biogas production and its methane content. The digested units were divided to two groups with six digested units for everyone. The first group was operated at ambient temperature $\left(27 \pm 2{ }^{\circ} \mathrm{C}\right)$. While, the second group was operated at Forty degree centigrade. The full capacity of each digested unit was 5 Liters while, the working capacity was 4 Liters (Fig. 1). The digester feeding consists of $3.2 \mathrm{~L}$ of cattle dung and $0.8 \mathrm{~L}$ of inoculum. The inoculum was obtained from an old operated biogas digester fed with cattle dung.

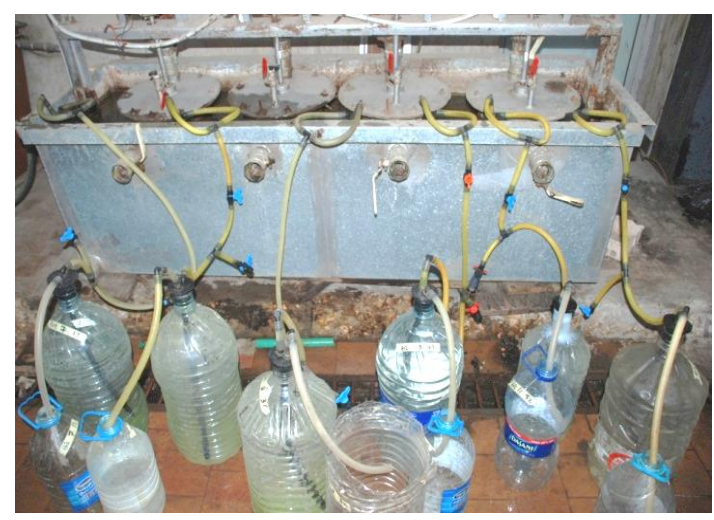

b: Experimental process at $40^{\circ} \mathrm{C}$

inside every digester. The average digestion total solids was $10 \%$ for every digester.

The amount of water added to digested materials for reaching the desirable total solid was estimated by equation (1), (LO et al., 1981).

$$
Y=X\left[\frac{T s_{m}-T s_{t}}{T s_{c}}\right] \quad \text { Liter }
$$

Where: $Y=$ Water volume $(L)$.

$$
\mathrm{X}=\text { Raw organic material, }(\mathrm{kg}) \text {. }
$$

$\mathrm{TS}_{\mathrm{m}}=$ Total solids of raw organic material, $(\%)$ and

$\mathrm{TS}_{\mathrm{d}}=$ Total solids of digested influent, $(\%)$.

The twelve digestion units used in the experimental work were divided in two groups. Every group consists of six digesters, which were feds as the follow; one digester (control) was fed with cattle manure only (G0). The other 
five digestion units were fed with cattle dung and crude glycerol at different percentages of 1, 2, 3, 4 and 5\% crude glycerol by weight, which was equivalent to $4,8,12,16$ and 20 gm respectively. The crude glycerol used in this experimental work was obtained from a biodiesel production unit and its chemical analysis was illustrated in Table (2). The total retention time was 60 days and the digesters were shake for three time during the light day.

Table 2. The chemical analysis of crude glycerol.

\begin{tabular}{lc}
\hline Contents & Value \\
\hline Fat $(\%)$ & 60.1 \\
Carbohydrates $(\%)$ & 26.9 \\
Protein $(\%)$ & 0.23 \\
Calories $(\mathrm{kJ} / \mathrm{kg})$ & 27.2 \\
Ash $(\%)$ & 5.50 \\
Water $(\%)$ & 12 \\
Viscosity, $\left(\mathrm{g} / \mathrm{cm}^{3}\right)$ & 1.2613 \\
\hline
\end{tabular}

The biogas production volume was measured twice a day using water displacement metering system under laboratory condition (Angelidaki et al., 1992) as shown in Fig. (2). Biogas samples were taken weekly from the reactor headspace. The daily biogas production was recalculated at the standard temperature pressure $\left(0{ }^{\circ} \mathrm{C}\right.$ and 1 bar) to adjust the biogas production volume under standard conditions using equation (2) (Gosch et al., 1983):

$$
\mathrm{V}_{\mathrm{tr}}=\frac{\mathrm{V}_{\mathrm{f}}\left[273.15\left(\mathrm{P}_{1}-\mathrm{P}_{2}-\mathrm{P}_{3}\right)\right]}{[273.15+\mathrm{T}] 1013} \mathrm{~m}^{3}
$$

\section{Where:}

$V_{\text {tr }}=$ gas volume under standard condition, $\left(\mathrm{m}^{3}\right)$

$V_{f}=$ volume of wet gas at pressure $P$ and temperature $T,\left(\mathrm{~m}^{3}\right)$

$\mathbf{P}_{1}=$ atmospheric pressure at temperature $T$, (in milli-bar)

$P_{2}=$ pressure of wet gas at temperature $T$, (in milli-bar)

$\mathbf{P}_{3}=$ saturation steam pressure of water at temperature $T$, (in milli-bar)

$1013=$ absolute pressure (in milli-bar) and

273.15 = standard temperature at $0^{\circ} \mathrm{C}(\mathrm{K})$.

The average two temperatures inside the digestion units through the experiments procedure period were; 27 and $40^{\circ} \mathrm{C}$. The gas pressure $(\mathrm{P} 2)$ ranged from 18.95 to 36.83 milli-bar with an average pressure of 29.33 milli-bar. In addition, the atmospheric pressure (P1) ranged from 1011 to 1018 milli-bar with the average of 1014 milli-bar at $25^{\circ} \mathrm{C}$.

Portable gas analyzer model of GA5000 (Geotechnical, UK) was used to measure methane (CH4), carbon dioxide (CO2), hydrogen sulfate $(\mathrm{H} 2 \mathrm{~S})$, Oxygen $(\mathrm{O} 2)$, Hydrogen (H2), gas pressure (P2) and atmospheric pressure (P1) (Fig. 3). Biogas compositions were measured every ten days to determine the methane content in produced biogas.

The digester output slurry was analyzed to determine its characteristics of alkalinity, $\mathrm{pH}$, total solids (TS), and volatile solids (VS) according to standard methods (APHA, 2005).

Table 3.The effect of crude glycerol and temperature on biogas production rate and cumulative.

\begin{tabular}{|c|c|c|c|c|c|c|}
\hline \multirow[t]{2}{*}{ Treatments } & \multicolumn{2}{|c|}{$\begin{array}{c}\text { Average biogas production } \\
\text { rate }(\mathrm{L} / \mathrm{L} / \text { day })\end{array}$} & \multicolumn{2}{|c|}{$\begin{array}{c}\text { Cumulative biogas } \\
\text { production, }(\mathbf{L})\end{array}$} & \multicolumn{2}{|c|}{$\begin{array}{c}\text { Increasing ratio, } \\
(\%)\end{array}$} \\
\hline & $27^{\circ} \mathrm{C}$ & $40{ }^{\circ} \mathrm{C}$ & $27^{\circ} \mathrm{C}$ & $40{ }^{\circ} \mathrm{C}$ & Biogas production rate & Cumulative \\
\hline$\overline{\text { G0 }}$ & 0.187 & 0.251 & 45.058 & 50.202 & 34.54 & 11.42 \\
\hline G1 & 0.191 & 0.263 & 46.105 & 52.549 & 37.84 & 13.98 \\
\hline $\mathrm{G} 2$ & 0.195 & 0.267 & 47.202 & 53.323 & 36.99 & 12.97 \\
\hline G3 & 0.200 & 0.278 & 48.615 & 55.407 & 38.90 & 13.97 \\
\hline G4 & 0.206 & 0.287 & 49.965 & 57.495 & 39.50 & 15.07 \\
\hline G5 & 0.212 & 0.296 & 51.489 & 59.279 & 39.62 & 15.13 \\
\hline
\end{tabular}

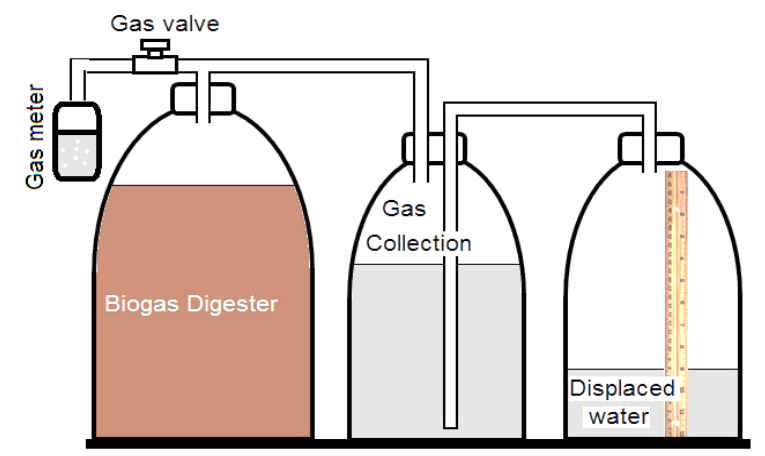

Fig. 2. Biogas measuring method using water displacement system

\section{Chemical analyses: \\ Total Solids:}

To determine the total solids percentage, samples of the fresh cattle dung and digester slurry were dried at $105 \pm$ $2{ }^{\circ} \mathrm{C}$ for 24 hours to reach constant weigh (APHA, 1989) using An electric oven model of WS 200, type 117-0200, temperature range up to $300{ }^{\circ} \mathrm{C}$.

\section{Volatile Solids.}

To determine the volatile solids percentage, the dried sample from the total solids was ignited at $600^{\circ} \mathrm{C}$ for two hours in a digital Muffle Furnace Model of F-14 (Korea), the temperature range of 100 to $1200{ }^{\circ} \mathrm{C}$. The loss in weight was considered as the volatile solids fraction of the total solids (APHA, 1989). The volatile solids (VS) mass in $\mathrm{kg}$ was determined using equation (3), (Wittmaier, 2003)

$$
\text { VS }(\mathrm{kg})=M \text { fresh } \times \text { VS }(\%)
$$

Organic matter and organic carbon (O.M \& O.C):

The percentage of organic matter was estimated from the percentage of ash using the equations 4 and 5 (Black et. al., 1965):-

$$
\begin{aligned}
& \text { O.M }(\%)=100(\%)-\operatorname{ash}(\%) . . . . . . . . .(4) \\
& \text { O.C }(\%)=\text { O.M }(\%) / \mathbf{1 . 7 4 2 1}
\end{aligned}
$$

\section{Data analysis:}

Excel spreadsheet was used to determine the averages of biogas production rate, biogas cumulative, biogas compositions, influent and effluent characteristics at different factors affecting biogas production throughout the experimental work.

\section{RESULTS AND DISCUSSION}

The effect of crude glycerol added to the digestion cattle manure at different percentages was investigated at different temperature conditions and crude percentages. The obtained results were listed in Table (3), the results clear that, the cumulative biogas production was increased with increasing temperature and crude glycerol percentages. 
1- Effect of crude glycerol addition on biogas production:

The effect of adding the crude glycerol to the digested cattle dung on biogas production rate and cumulative at ambient temperature $\left(27^{\circ} \mathrm{C}\right)$ was illustrated in Figs. (3 and 4) The biogas production rate was increased at different treatments with the retention time reached the maximum values of $0.358 \mathrm{~L} / \mathrm{L} /$ day at 21 th day for $\mathrm{G} 0$, $0.360,0.365$ and $0.367 \mathrm{~L} / \mathrm{L} /$ day for $\mathrm{G} 1, \mathrm{G} 2$ and $\mathrm{G} 3$ respectively at 20th day, $0.374 \mathrm{~L} / \mathrm{L} /$ day for $\mathrm{G} 4$ at 19 th day, and $0.391 \mathrm{~L} / \mathrm{L} /$ day for G5 at 18th day. However, the cumulative biogas production increased with increase the glycerol percentage. The maximum biogas cumulative at $27{ }^{\circ} \mathrm{C}$ was $51.489 \mathrm{~L}$ and it occurred at glycerol percentage of $5 \%$ ( $20 \mathrm{~g}$ of glycerol addition). The increasing ratios of biogas production due to add of crude glycerol were; 2.32 , 4.76, 7.90, 10.89 and $14.27 \%$ at G1, G2, G3, G4, and G5 respectively as compared with G0 (without crude glycerol).

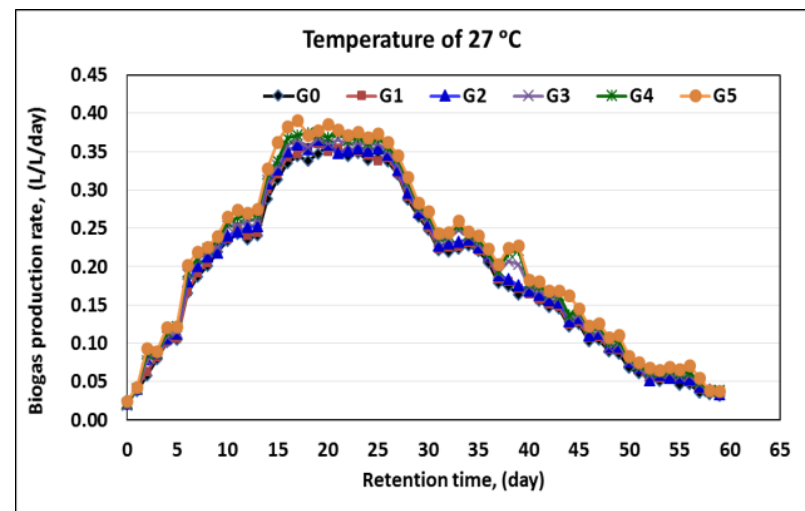

Fig. 3. Biogas production rate with different treatments at $27^{\circ} \mathrm{C}$

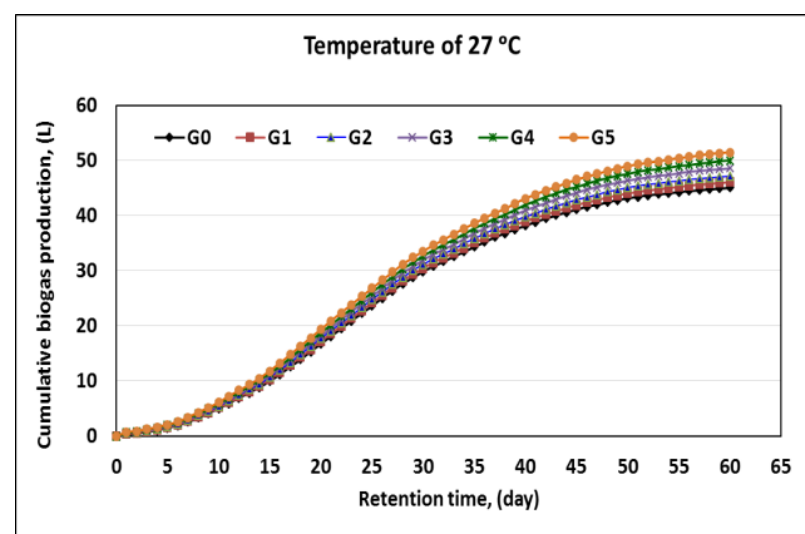

Fig. 4. Cumulative biogas production with different treatments at $27^{\circ} \mathrm{C}$

2- Effect of crude glycerol addition on biogas production:

The effect of adding the crude glycerol to the digested cattle dung on biogas production rate and cumulative at ambient temperature $\left(27^{\circ} \mathrm{C}\right)$ was illustrated in Figs. (3 and 4). The biogas production rate was increased at different treatments with the retention time reached the maximum values of $0.358 \mathrm{~L} / \mathrm{L} /$ day at $21^{\text {th }}$ day for G0, 0.360, 0.365 and $0.367 \mathrm{~L} / \mathrm{L} /$ day for $\mathrm{G} 1, \mathrm{G} 2$ and $\mathrm{G} 3$ respectively at $20^{\text {th }}$ day, $0.374 \mathrm{~L} / \mathrm{L} /$ day for $\mathrm{G} 4$ at $19^{\text {th }}$ day, and $0.391 \mathrm{~L} / \mathrm{L} /$ day for $\mathrm{G} 5$ at $18^{\text {th }}$ day. However, the cumulative biogas production increased with increase the glycerol percentage. The maximum biogas cumulative at $27^{\circ} \mathrm{C}$ was $51.489 \mathrm{~L}$ and it occurred at glycerol percentage of $5 \%$ ( $20 \mathrm{~g}$ of glycerol addition). The increasing ratios of biogas production due to add of crude glycerol were; 2.32, $4.76,7.90,10.89$ and $14.27 \%$ at G1, G2, G3, G4, and G5 respectively as compared with G0 (without crude glycerol).

On the other hand, the biogas production rates and cumulative at $40{ }^{\circ} \mathrm{C}$ were fitted in Figs. (5 and 6). The maximum biogas production rates were; $0.464,0.470$, and $0.474, \mathrm{~L} / \mathrm{L} /$ day for $\mathrm{G} 0, \mathrm{G} 1$, and $\mathrm{G} 2$, respectively at $19^{\text {th }}$ day, $0.483 \mathrm{~L} / \mathrm{L} /$ day for $\mathrm{G} 3$ at $18^{\text {th }}$, and 0.505 , and 525 $\mathrm{L} / \mathrm{L} /$ day for G4 and G5 respectively at $17^{\text {th }}$ day. However, the maximum biogas production was $59.279 \mathrm{~L}$ at G5 with increasing ratio of $18.08 \%$ as compared with G0 (control treatment). The increasing ratios of different treatments were; 4.67, 6.22, 10.37 and $14.53 \%$ at G1, G2, G3, and G4 respectively, as compared with G0. From the previous results we can be noted that the biogas production rates and cumulative were increased with increasing the crude glycerol addition, this increasing may be due to high ratios of fats and carbohydrates in crude glycerol.

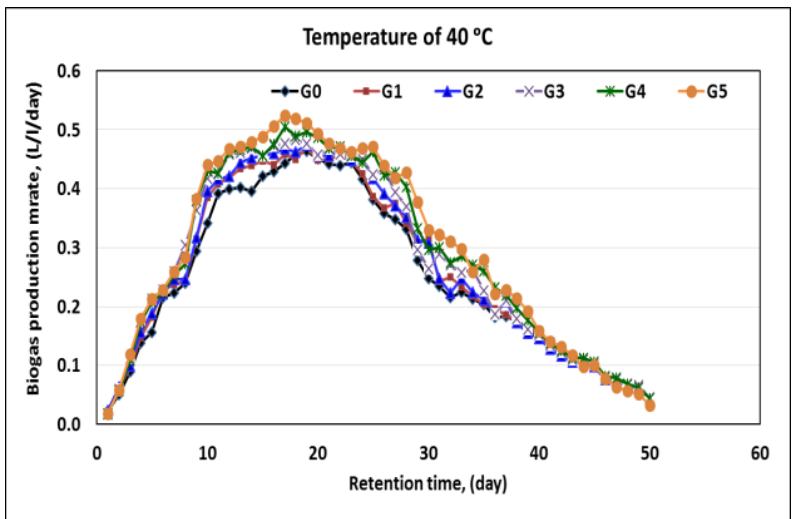

Fig. 5. Biogas production rate at different treatments and $40{ }^{\circ} \mathrm{C}$

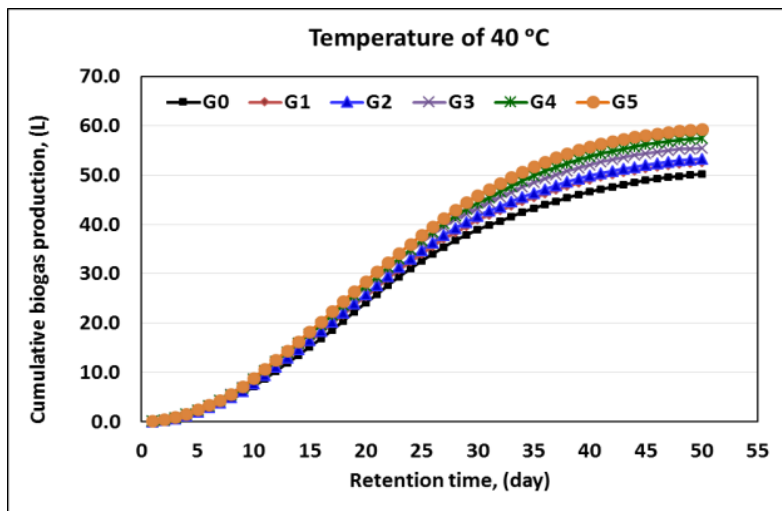

Fig. 6. Cumulative biogas production at different treatments and $40{ }^{\circ} \mathrm{C}$

\section{3- Effect of temperature on biogas production:}

Effect of temperature on biogas production rate was illustrated in Figs. (7, 8, 9, 10, 11 and 12). The obtained data indicated that increasing digestion temperature from $27{ }^{\circ} \mathrm{C}$ to $40{ }^{\circ} \mathrm{C}$ increase the biogas production rate from; 0.187 to $0.251,0.191$ to $0.263,0.195$ to $0.267,0.200$ to $0.278,0.206$ to 0.287 , and 0.212 to $0.296 \mathrm{~L} / \mathrm{L} /$ day at G0, G1, G2, G3, G4, and G5 respectively. The increasing ratios were; $11.42,13.98,12.97,13.97,15.07$, and $15.13 \%$ at the same treatments respectively. 


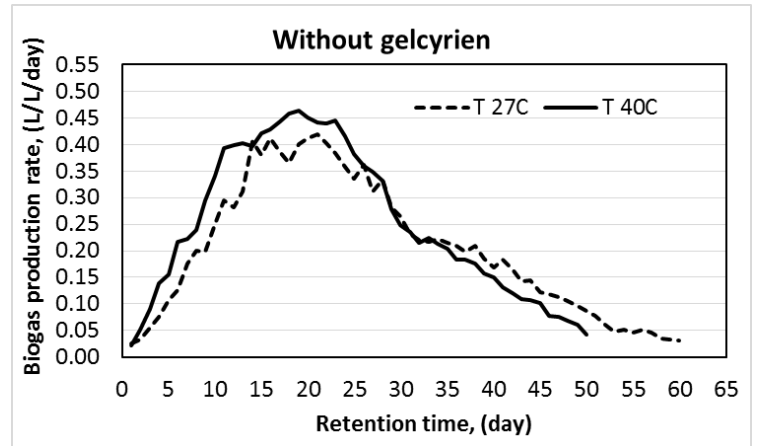

Fig. 7. Effect of temperature on biogas production rate at 0 glycerol added

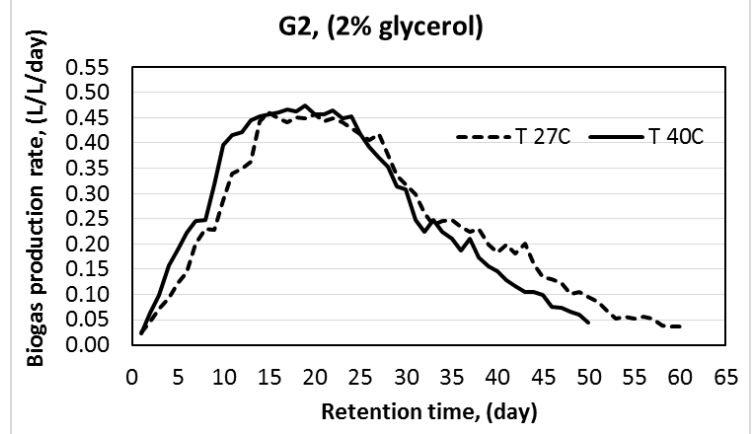

Fig. 9. Effect of temperature on biogas production rate at $2 \%$ glycerol added

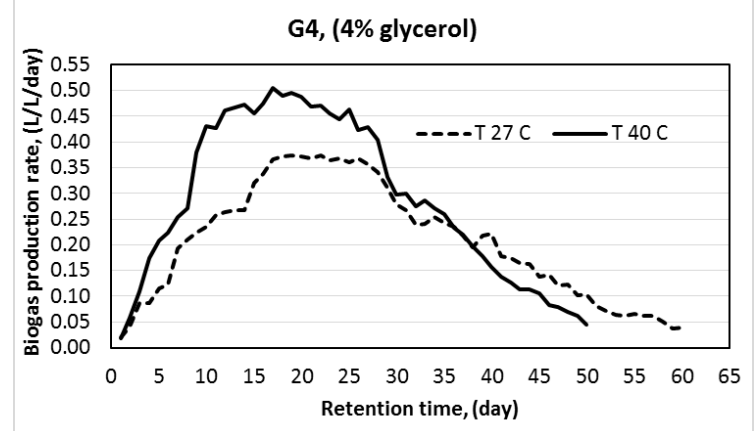

Fig. 11. Effect of temperature on biogas production rate at $4 \%$ glycerol added

In addition, the total biogas production was increased from; 45.058 to $50.202,46.105$ to $52.549,47.202$ to $53.323,48.615$ to $55.407,49.965$ to 57.495 , and 51.489 to $59.279 \mathrm{~L}$ at different treatments of G0, G1, G2, G3, G4, and G5 respectively, with increasing ratios of; 11.42 , $13.98,12.97,13.97,15.07$, and $15.13 \%$ at the same treatments respectively.

4- Effect of crude glycerol and temperature levels on the methane content:

Effect of crude glycerol and temperature levels on methane content of biogas production from cattle dung were illustrated in Figs. (13 and 14). The obtained data clear that the average methane content of biogas was increased with increasing crude glycerol addition and digestion temperatures. From Fig. (13), it can be noted that the average methane content was increased with increasing crude glycerol addition percentage. The increasing ratios were; $1.74,2.03,2.91,4.07$, and $4.65 \%$ at G1, G2, G3, G4, and G5 respectively as compared with $\mathrm{G} 0$ (without crude glycerol). Moreover, increasing the digestion temperature to $40{ }^{\circ} \mathrm{C}$ increase the methane content at different crude glycerol

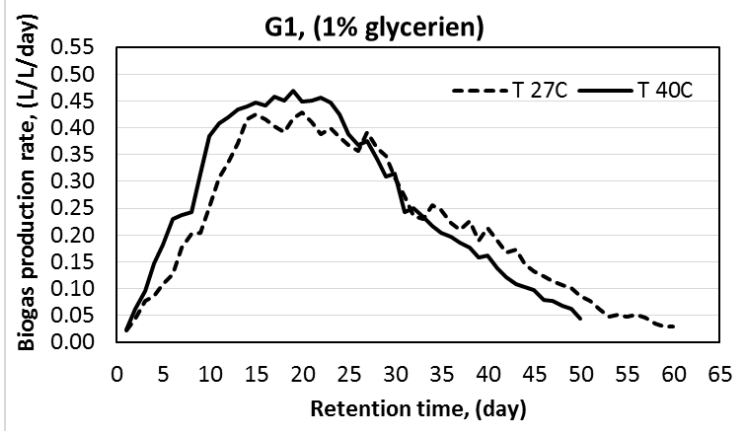

Fig. 8. Effect of temperature on biogas production rate at $1 \%$ glycerol added

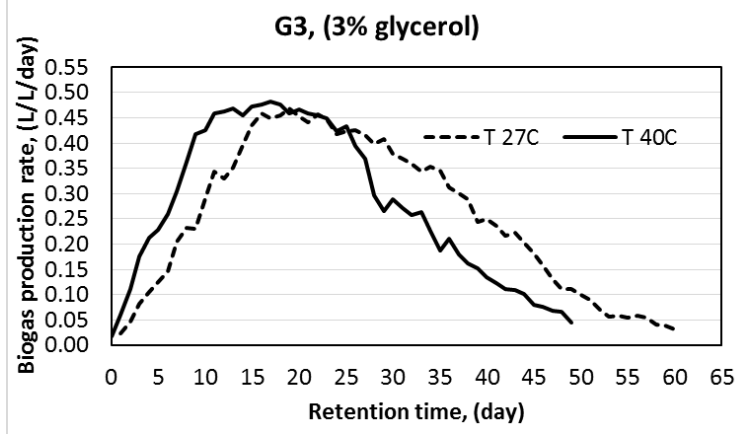

Fig. 10. Effect of temperature on biogas production rate at $3 \%$ glycerol added

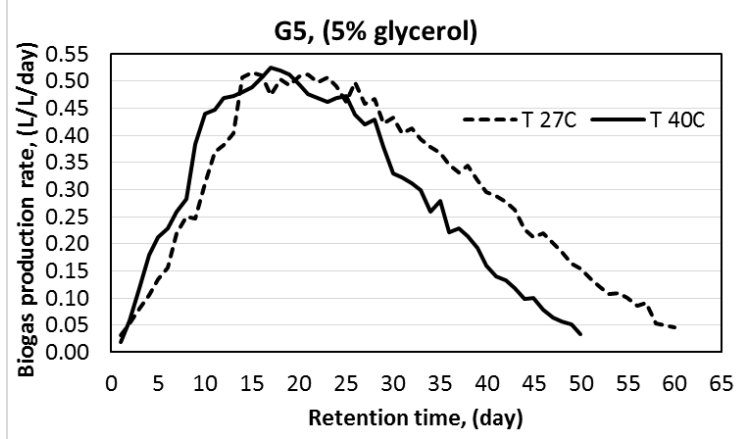

Fig. 12. Effect of temperature on biogas production rate at $5 \%$ glycerol added

percentages. The maximum value of methane content was $66 \%$ with increasing ratio of $8.28 \%$ as compared with nonglycerol added and it occurred at crude percentage of $5 \%$ and $40{ }^{\circ} \mathrm{C}$. This results was in agreement with Robra et al., (2010). The increasing ratios of methane content at $40{ }^{\circ} \mathrm{C}$ were; 3.79, 4.48, 4.83, and 6.55, at G1, G2, G3 and G4 respectively as compared with G0.

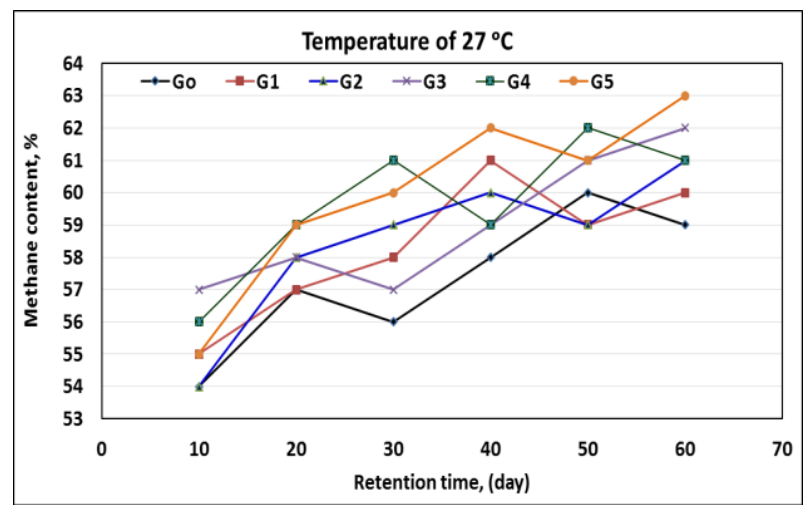

Fig. 13. Effect of glycerol added on methane content at $27^{\circ} \mathrm{C}$ 


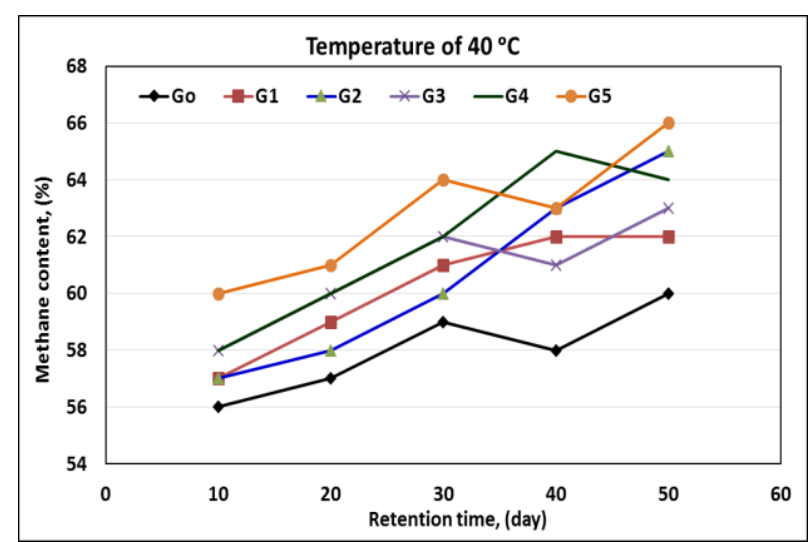

Fig. 14. Effect of glycerol added on methane content at $40{ }^{\circ} \mathrm{C}$

Moreover, increasing digestion temperature from 27 to $40{ }^{\circ} \mathrm{C}$ increase the average methane content with about; 1.16, 3.20, 3.59, 3.05, 3.58, and $4.67 \%$ at different treatments of G0, G1, G2, G3, G4, and G5 respectively.

\section{CONCLUSION AND RECOMMENDATIONS}

The obtained results showed that the addition of crude glycerol to cattle dung during anaerobic digestion increased the biogas production rate and consequently the total biogas production at 27 and $40{ }^{\circ} \mathrm{C}$ temperatures. Moreover, increasing the percentage of crude glycerol added increase the biogas production rate reached the maximum values of 0.212 and $0.296 \mathrm{~L} / \mathrm{L} /$ day at $\mathrm{G} 5(5 \%$ crude glycerol added about $20 \mathrm{~g}$ ) and temperatures of $27{ }^{\circ} \mathrm{C}$ and $40{ }^{\circ} \mathrm{C}$, respectively as compared with G0 (0 crude glycerol added). The increasing ratios were; 13.60 and $17.89 \%$ at the same temperatures respectively. In addition, the total biogas production reached the maximum values of; 51.489 and $59.279 \mathrm{~L}$ at the treatment of G5 temperatures of 27 and $40{ }^{\circ} \mathrm{C}$, respectively, with increasing ratios of 14.27 and $18.08 \%$ at the same temperatures as compared with G0. These increases in biogas production may be due to high ratios of fats and carbohydrates in crude glycerol. The maximum value of methane content was $66 \%$ and it was occurred at $5 \%$ crude glycerol and temperature of $40^{\circ} \mathrm{C}$.

It is highly recommended that more research works will be required to evaluate the addition of highest percentages of crude glycerol on biogas production from different organic materials at wide range of temperatures and different digestion methods (batch, semi-continuous, and continuous type).

\section{REFERENCES}

Angelidaki I., L. Ellegaard and B.K. Ahring (1992). Compact automated displacement gas metering system for measurement of low gas rates from laboratory fermenters. Biotechnology and Bioengineering 39, 351-353.

Amon T., B. Amon, V. Kryvoruchko, V. Bodiroza, E. Potsch and W. Zollitsch. (2006). Optimising methane yield from anaerobic digestion of manure: Effects of dairy systems and of glycerine supplementation. Intl. Congress Series 1293: 217-220.
APHA (American Puplic Health Assocition). (1989) "Standard methods for the examination of water and waste water" 17 th. ed . Washington, D.C. USA.

APHA. (2005). Standard Methods for the Examination of Water and Wastewater. 21st ed. Washington, D.C.: American Public Health Association.

Ayoub M, and AZ., Abdullah (2012). Critical review on the current scenario and significance of crude glycerol resulting from biodiesel industry towards more sustainable renewable energy industry. Renew Sustain Energy Rev 16:26712686.

Black, C. A.; Evans, D. O.; Ensminger, L. E.; White, J. L.; Clark, F. C.; and Dineuer (1965) "Methods of soil analysis". II-chemical and microbiological properties. American Soc. Agron. Inc. Madison. Wisconsin. USA.

Chozhavendhan S, R.P. Kumar, B. Bharathiraja; and M. Jayakumar (2016). Recent progress on transforming crude glycerol into high value chemicals: a critical review. Biofuels. https://doi. org/10.1080/ 17597269. 2016.1174018.

Chozhavendhan. S.,R., P. Kumar, S. Elavazhagan, B. Barathiraja, M. Jayakumar and S.J. Varjani. (2018). Utilization of Crude Glycerol from Biodiesel Industry for the Production of Value-Added Bioproducts. Chapter 4.Waste to Wealth, Energy, Environment, and Sustainability, https://doi.org/ 10.1007/ 978-98110-7431-8_4.

Da Silva, G.P., M. Mack, and J. Contiero (2009). Glycerol: a promising and abundant carbon source for industrial microbiology. Biotechnol. Adv. 27, 30-39

Demirbas A., (2007). Importance of biodiesel as transportation fuel. Energy Pol. 35(9):4661-4670.

Dharmadi. Y, A. Murarka, and R. Gonzalez, (2006). Anaerobic fermentation of glycerol by Escherichia coli: A new platform for metabolic engineering, Biotechnol. Bioeng. 94 ,pp. 821829.

Erin J, S. Tahereh, K. Sascha, M. Garret, and R. Lars (2016). Consolidating biofuel platforms through the fermentative bioconversion of crude glycerol to butanol. World J MicrobiolBiotechnol 32:1-14.

Fierro J, E.J. Martinez, J.G.Rosas, R.A. Fernández, R. López, and X. Gomez (2016). Co-digestion of swine manure and crude. Water Air Soil Pollut. 227:78. http://dx.doi.org/ 10.1007/s11270-0162773-7.

Flach. B., S., A. Lieberz, S. Rossetti, and E.U. Phillips (2017). Biofuels Annual Report.

Fountoulakis M.S. and T. Manios, (2010). Enhanced methane and hydrogen production from municipal waste and agro-industrial by-products co-digested with glycerol, Bioresource Technology, 100, 30433047.

Gosch, A.; M. Hildegart; W. Ursula and J. Walter (1983).The anaerobic treatment of poultry manure. Animal Res. and Dev. vol. 17: 62-73.

Grady Jr, C.P.L., G.T. Da igger, N.G.Love, and C.D.M. Filipe, (2011). Biological Wastewater Treatment 63, 632. 
Holm-Nielsen, J., C. Lomborg, P. Oleskowicz-Popiel, and K. Esbensen,(2008). On-Line near infrared monitoring of glycerol-boosted anaerobic digestion processes: evaluation of process analytical technologies. Biotechnology and Bioengineering, 99, pp.302-313

Houcinat I., Q. Nawel and A.H. Meniai (2018). Optimization of gas production and efficiency of supercritical glycerol gasification using response surface methodology. Biofuels, DOI: 10.1080/17597269.201 8.1433968

Leoneti A.B., V. Aragão-Leoneti, and S.V.W.B. de Oliveira (2012). Glycerol as a by-product of biodiesel production in Brazil: alternatives for the use of unrefined glycerol. Renew Energy; 45:138-45. http://dx.doi.org/10.1016/j.renene.2012.02.032.

Lo K V., W.M. Carson and K. Jeffers (1981). A Computeraided design program for biogas production from animal manure. Livestock Waste: A Renewable Resource 133-135, 141.

Mata-Alvarez J., J. Dosta, M.S. Romero-Güiza, X. Fonoll, M. Peces and S. Astals (2014). A critical review on anaerobic co-digestion achievements between 2010 and2013. Renewable and Sustainable Energy Reviews, 36, pp. 412-427.

Nartker S., M. Ammerman J. Aurandt, M. Stogsdil, O. Hayden and C. Antle (2014). Increasing biogas production from sewage sludge anaerobic codigestion process by adding crude glycerol from biodiesel industry. Waste Manag; 34:2567-71. http:// dx.doi.org/10.1016/j.wasman.2014.08.017.

Quan (Sophia) He, J. McNutt and J. Yang (2016). Utilization of the residual glycerol from biodiesel production for renewable energy generation. Renewable and Sustainable Energy Reviews. Vol. 71. Pp 63-76. doi.org/10.1016/j.rser.2016.12.110.

Robra S., R.S. Cruz, A.M.Oliveira, J.A.A. Neto, and J.V. Santos (2010). Generation of biogas using crude glycerin from biodiesel production as a supplement to cattle slurry, Biomass and Bioengineering, 34: 1330-1335.
Siles Lopez J.A., L. Martin Santos M.de, A.F. Chica and A. Perez (2009). Martin, Anaerobic digestion of glycerol derived from biodiesel manufacturing. Bioresour. Technol. 100: 56095615.

Wittmaier M. (2003). Co-fermentation of organic substrates in the decentralized production of regenerative energy. Workshop; "Technologies of Municipal Waste Treatment- Experiences and Challenges", Hanoi Uni. Sc., Vietnam.

Varrone C., T.M.B. Heggeset, S.B. Le, T. Haugen, S. Markussen and I.V. Skiadas (2015). Comparison of different strategies for Selection/Adaptation of mixed microbial cultures able to ferment crude glycerol derived from second-Generation biodiesel, Biomed. Res. Int. 14, http://dx.doi.org/ 10.1155/2015/932934.

Viana M.B.; A.V. Freitas, R.C. Leitão, G.A.S. Pinto and S. T. Santaella (2012). Anaerobic digestion of crude glycerol: a review, Environmental Technology Reviews, 1:1, 81-92, DOI: 10.1080/09593330.2012. 692723.

Vinayak L.P., S.J. Sarma, S.K. Brar, Y. Le Bihan, G. Buelna and M. Verma (2016). Energy balance of hydrogen production from wastes of biodiesel production, Biofuels, 9:2, 129-138, DOI: 10.1080/ 17597269. 2016.1153361

Yazdani S.S. and R. Gonzalez (2007). Anaerobic fermentation of glycerol: a path to economic viability for the biofuels industry, Curr. Opin.Biotechnol.18 (2007)213-219, http://dx.doi.org/10.1016/ j.copbio. 2007.05.002.

Waala A.E., S.Y. Aymen, E.A. Amal and A.M. Magdy (2016). Utilization of crude glycerol as a substrate for the production of Rhamnoliid by Pseudomonas aeruginosa. Biotech Research Int 1-9.

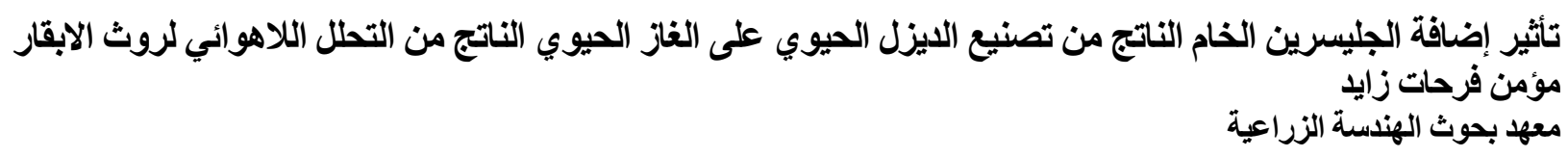

يهدف هذا البحث الى دراسة تأثير إضافة الجلسرين ومحتو اه من الميثان الخام الناتج من إنتاج البيوديزل على إنتاج الغاز الحيوي الناتج من

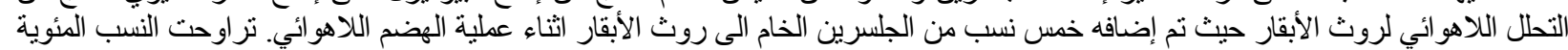

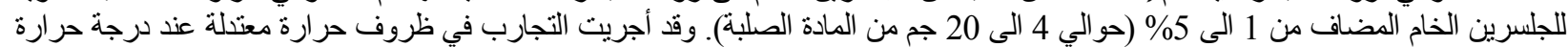

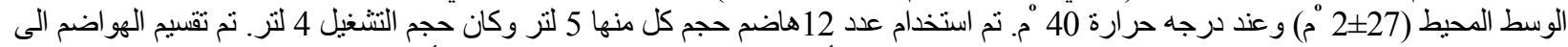

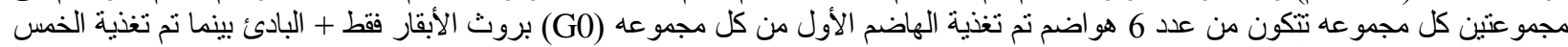

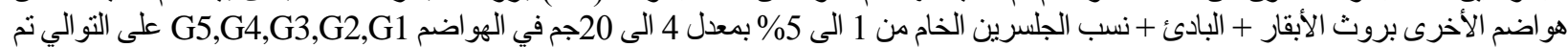

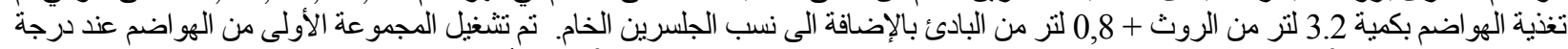

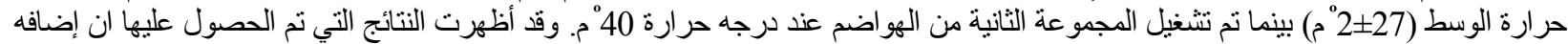

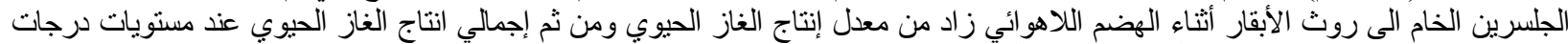

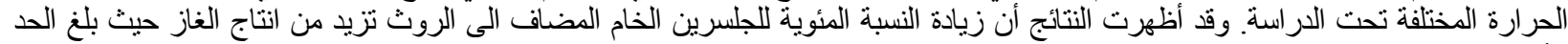

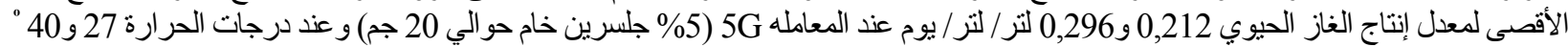

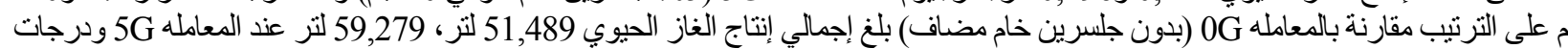

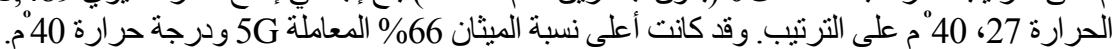

